\title{
molecules
}

ISSN 1420-3049

http://www.mdpi.org

Full Paper

\section{Ionic Liquid-promoted Ring-closure Reactions between 1,4-Dihydroxyanthraquinone and Diamines}

\author{
Zhang-Gao Le ${ }^{1, *}$, Zong-Bo Xie ${ }^{1}$ and Min Ying ${ }^{2}$ \\ ${ }^{1}$ Department of Applied Chemistry, East China Institute of Technology, Fuzhou, 344000, Jiangxi, P. \\ R. China; E-mail:; Telephone: (+86)-794-8250216; Fax: (+86)-794-8258310 \\ ${ }^{2}$ Zhejiang Wanli University, Ningbo, 315100, Zhejiang, P. R. China; E-mail: Yingm@zwu.edu.cn
}

* Author to whom correspondence should be addressed; e-mail: Lezhang_ecit@163.com

Received: 10 May 2006; in revised form: 15 June 2006 / Accepted: 19 June 2006 / Published: 21 June 2006

\begin{abstract}
The reaction of 1,4-Dihydroxyanthraquinone with diamines was carried out in the presence of $\mathrm{CuCl}_{2}, \mathrm{CuCl}$ in the ionic liquid $[\mathrm{Bmim}] \mathrm{PF}_{6},[\mathrm{Bmim}] \mathrm{BF}_{4}$ or $[\mathrm{Bmim}] \mathrm{Cl} \cdot \mathrm{CuCl}$.
\end{abstract}

Keywords: Ionic liquid, 1,4-dihydroxyanthraquinone, diamines, ring-closure.

\section{Introduction}

There is currently renewed interest in aminoanthraquinones. The use of mono- and diaminothraquinones in the dyestuffs industry has been well established for many years, but recently a number of other features of aminoanthraquinone chemistry have attracted intense interest. A review of the fascinating enediyne anticancer antibiotics details the role of anthraquinones such as dynemicin A in the cleavages of DNA [1]. In certain cases [2] there is also evidence that an anthraquinone moiety can intercalate into DNA and a side arm of the anthraquinone, for example an alkylamino substituent, can bind to protein and in such cases, due to disruption of DNA-protein interactions there can be interference with topoisomerase II and antitumor activity is observed. Other important aspects of DNA cleavage by anthraquinones have recently been discussed [3]. These exciting biological results with dynemicin A have stimulated synthesis of key sub-units. A tetracycle [4] having a core aminoanthraquinone portion related to dynemicin A has recently been synthesized, and related pentacycles have also been prepared [5]. Other aminoanthraquinones such as mitoxantrone and 
ametantrone are now used clinically. A large number of papers and patents have been reported on substitution reactions for introducing amino groups into the anthraquinone moiety, but little is known about the direct amination of this nucleus. The direact amination of anthraquinone or aminoanthraquinones with hydroxylamine catalyzed by iron sulfate or vanadium pentaoxide has been described, but it produces random substitution products. Takei et al. have reported direct amination of anthraquinone promoted by copper ions [6]. However, their reaction conditions are rather drastic, requiring the use of copper salt in greater than stoichiometric amounts and the use of toxic pyridine. Therefore, the development of a simple, relatively mild, efficient and environmentally more benign method for the synthesis of aminoanthraquinones would be of great utility.

Our recent research interests have been in the development of new synthetic method using ionic liquids as reaction media and promoters [7]. As part of a program to investigate the range of organic reactions possible in ionic liquids, we examined the reactions of 1,4-dihydroxyanthraquinone and diamines $\mathrm{NH}_{2} \mathrm{RNH}_{2}$ in ionic liquids (Scheme 1).

\section{Scheme 1}<smiles>O=C1c2ccccc2C(=O)c2c(O)ccc(O)c21</smiles>

1<smiles>CC(Cl)(Cl)CCCCNN</smiles>

2<smiles>[R]Nc1ccc2c(C(=O)c3ccccc3C)c1NC2</smiles>

3

$$
\begin{aligned}
& \mathrm{R}=-\mathrm{CH}_{2} \mathrm{CH}_{2}-\quad \mathrm{R}=-\mathrm{CH}_{2} \mathrm{CHCH}_{3} \\
& \mathrm{R}=-\mathrm{CH}_{2} \mathrm{CHCH}_{2} \mathrm{CH}_{3} \mathrm{R}=
\end{aligned}
$$

\section{Results and Discussion}

First, the ring-closure reaction of 1,4-dihydroxyanthraquinone and ethylenediamine was investigated. The results are presented in Table 1 . We found that in the presence of $20 \mathrm{~mol} \% \mathrm{CuCl}_{2}$, the reaction of 1,4-dihydroxyanthraquinone and ethylenediamine in the ionic liquid [Bmim] $\mathrm{PF}_{6}$ resulted in the formation of 6-hydroxy-1,2,3,4-tetrahyronaphtho[2,3-f]-quinoxaline-7,12-dione in 99\% yield, and that the reaction proceeded smoothly at room temperature and was complete within 2 hours. In a similar fashion, the reactions of 1,4-dihydroxyanthraquinone and ethylenediamine in different ionic liquids and classical solvents were investigated. The results demonstrated that the ionic liquids $[\mathrm{Bmim}] \mathrm{PF}_{6},[\mathrm{Bmim}] \mathrm{BF}_{4},[\mathrm{Bmim}] \mathrm{Cl} \cdot \mathrm{CuCl}$ were effective and promoted ring-closure reaction between 1,4-dihydroxyanthraquinone and the diamine (Table 1, Entries 1-5). The yields in classical solvents were lower than those observed using ionic liquids (Table 1, Entries 6-9).

The scope of the reaction of different diamines with 1,4-dihydroxyanthraquinone was investigated next. We found that the reaction occurred easily in $[\mathrm{Bmim}] \mathrm{PF}_{6}$ in the presence of $20 \mathrm{~mol} \% \mathrm{CuCl}_{2}$ to form the corresponding products. The yields with 1,2-propanediamine and 1,2-cyclohexanediamine 
were excellent, while the yields with $N$-methylenthylenediamine and $N$-ethylenthylenediamine were modest (Table 1, Entries 10-13). All the products gave satisfactory M.p., IR and ${ }^{1} \mathrm{H}-\mathrm{NMR}$ data, which were consistent with the literature data.

The ionic liquid and copper salt could typically be recovered by extracting the product and washing with a mixture of $\mathrm{Et}_{2} \mathrm{O}-\mathrm{EtOAc}$ (1:1), followed by drying under vacuum. The recovered ionic liquid and copper salt could be reused at least up to five times with no appreciable decrease in yield.

Table 1. Reaction of 1,4-Dihydroxyanthraquinone and Diamines catalyzedcopper salt in ionic liquids ${ }^{\mathrm{a}}$.

\begin{tabular}{|c|c|c|c|c|}
\hline $\begin{array}{l}\text { Entr } \\
\mathrm{y}\end{array}$ & Diamine & Solvent and Copper salt & Reaction time (h) & Yield $^{\mathrm{b}}(\%)$ \\
\hline 1 & ethylenediamine & {$[\mathrm{Bmim}] \mathrm{PF}_{6}+\mathrm{CuCl}_{2}$} & 2 & 99 \\
\hline 2 & ethylenediamine & {$[\mathrm{Bmim}] \mathrm{PF}_{6}+\mathrm{CuCl}$} & 2 & 95 \\
\hline 3 & ethylenediamine & {$[\mathrm{Bmim}] \mathrm{Cl} \cdot \mathrm{CuCl}$} & 2 & 87 \\
\hline 4 & ethylenediamine & {$[\mathrm{Bmim}] \mathrm{BF}_{4}+\mathrm{CuCl}$} & 2 & 90 \\
\hline 5 & ethylenediamine & {$[\mathrm{Bmim}] \mathrm{BF}_{4}+\mathrm{CuCl}_{2}$} & 2 & 96 \\
\hline 6 & ethylenediamine & $\mathrm{CuCl}_{2}+\mathrm{DMF}$ & 8 & 56 \\
\hline 7 & ethylenediamine & $\mathrm{CuCl}+\mathrm{DMF}$ & 8 & 42 \\
\hline 8 & ethylenediamine & $\mathrm{CuCl}_{2}+\mathrm{CH}_{2} \mathrm{Cl}_{2}$ & 8 & 50 \\
\hline 9 & ethylenediamine & $\mathrm{CuCl}+\mathrm{CH}_{2} \mathrm{Cl}_{2}$ & 8 & 40 \\
\hline 10 & 1,2-propanediamine & {$[\mathrm{Bmim}] \mathrm{PF}_{6}+\mathrm{CuCl}_{2}$} & 2 & 92 \\
\hline 11 & 1,2-cyclohexanediamine & {$[\mathrm{Bmim}] \mathrm{PF}_{6}+\mathrm{CuCl}_{2}$} & 2 & 80 \\
\hline 12 & $\mathrm{~N}$-methylenthylenediamine & {$[\mathrm{Bmim}] \mathrm{PF}_{6}+\mathrm{CuCl}_{2}$} & 2 & 48 \\
\hline 13 & $N$-ethylenthylenediamine & {$[\mathrm{Bmim}] \mathrm{PF}_{6}+\mathrm{CuCl}_{2}$} & 2 & 31 \\
\hline
\end{tabular}

\section{Conclusions}

In summary, we have demonstrated that the ring closure reaction between 1,4-dihydroxyanthraquinone and diamines can be performed effectively at room temperature in the ionic liquids 1butyl-3-methylimidazolium hexafluorophosphate $\left([\mathrm{Bmim}] \mathrm{PF}_{6}\right)$ or 1-butyl-3-methylimidazolium tetraflouoraborate $\left([\mathrm{Bmim}] \mathrm{BF}_{4}\right)$ or with copper (I) chloride-1-butyl-3-methylimidazolium chloride $([\mathrm{Bmim}] \mathrm{Cl} \cdot \mathrm{CuCl})$, thus providing a simple and efficient synthetic method. This method has many obvious advantages compared to those previously reported in the literature, including being environmentally more benign, the simplicity of the methodology, the higher yields obtained and the potential for recycling of the ionic liquids and catalyst copper salt.

\section{Acknowledgements}

Project supported by the Science Foundation of JiangXi Province (No. 0520001) and Zhejiang Province (Y404288), the Science and Technology Foundation of the Education Department of JiangXi Province and the President Foundation of East China Institute of Technology. 


\section{Experimental Section}

\section{General}

Melting points were determined on a digital melting point apparatus and were not corrected. Infrared spectra were recorded on a Bruker VECTOR 22 instrument. Nuclear magnetic resonance spectra were recorded on a Bruker AVANCE DMX 200 spectrometer. The ionic liquids $\left[\mathrm{Bmim}^{-} \mathrm{BF}_{4}\right.$, $[\mathrm{Bmim}] \mathrm{PF}_{6}$ and $[\mathrm{Bmim}] \mathrm{Cl} \cdot \mathrm{CuCl}$ were synthesized according to reported procedures [8]. The other materials are commercially available and were used without further purification.

\section{General synthetic procedure}

1,4-Dihydroxyanthraquinone (2 mmol), the appropriate diamine (4 mmol) and copper salt $(0.4$ mmol) were added to the selected ionic liquid ([Bmim] $\left[\mathrm{PF}_{6}\right]$ or $\left[\mathrm{Bmim}_{\mathrm{B}} \mathrm{BF}_{4}, 2 \mathrm{~mL}\right.$ ) and the mixture was stirred at room temperature for $2 \mathrm{~h}$. The product was then extracted with ether (3x10 mL). The combined ethereal phase was evaporated under reduced pressure to give the crude product, which was purified by recrystallization to give the corresponding pure compound. After removal of the product, the residue of the viscous ionic liquid and copper salt was further washed with a 1:1 mixture of etherethyl acetate, dried at $80^{\circ} \mathrm{C}$ under reduced pressure for several hours and reused in subsequent runs.

\section{References}

1. Patrice, J. G.; John, M. M.; Glynn, D. M. Reaction of Imines of Aminoanthraquinones with Formaldehyde and Alkenes. Tetrahedron 1995, 51, 6133-6144.

2. Krapcho, A. P.; Petry, M. E.; Getahun, Z.; Landi, J. J.; Stallman, J.; Polsenberg, J. F.; Gallagher, C. E.; Maresch, M.J.; Hacker, M. P.; Giliani, F.C.; Beggiolin, G.; Pezzoni, G.; Menta, E.; Manzotti, C.; Oliva, A.; Spinelli, S.; Tognella, S. 6,9-Bis[(aminoalkyl)amino]benzo[g]-isoquinoline-5,10diones. A Novel Class of Chromophore-Modified Antitumor Anthracene-9,10-diones: Synthesis and Antitumor Evaluations. J. Med. Chem. 1994, 37, 828-837.

3. Amitage, B.; Yu, C.; Devadoss, C.; Schuster, G. B. Cationic Anthraquinone Derivatives as Catalytic DNA Photonucleases: Mechanisms for DNA Damage and Quinone Recycling. J. Am. Chem. Soc. 1994, 116, 9847-9859.

4. Magnus, P.; Eisenbeis, S. A.; Magnus, N. A.; A Concise Sythesis of the Anthraquinone Portion of Dynemicin-A. J. Chem. Soc. Chem. Comm. 1994, 1545-1546.

5. Nicolaou, K.C.; Gross, J. L.; Kerr, M. A.; Lemus, R. H.; Ikeda, K.; Ohe, K. Synthesis of the Anthraquinone Framework of Dynemicin A. Angew. Chem. Int. Ed. Engl. 1994, 33, 781-783.

6. (a) Toshio, T.; Masaru, M.; Teijiro, K. A Novel Ring-closure Reaction between 1,4-Dihydroxyanthraquinone and Diamines Promoted by Copper Ions. Bull. Chem. Soc. Jpn. 1981, 54, 2735-2738;

(b) Toshio, T.; Masaru, M.; Teijiro, K. A Novel Ring Closure Reaction between 1,4Dihydroxyanthraquinone and Diamines Promoted by Copper Ions. Chem. Lett. 1980, 743-744.

7. (a) Le, Z. G.; Chen, Z. C.; Hu, Y.; Zheng, Q. G. Organic Reaction in Ionic Liquids: N-alkylation of Phthalimide and Several Nitrogen Heterocycles. Synthesis 2004, 208-212; (b) Le, Z. G.; Chen, Z. 
C.; Hu, Y.; Zheng, Q. G. Organic Reactions in Ionic liquids: ionic liquid-promoted efficient synthesis of N-alkyl and N-arylimides. Synthesis 2004, 995-998; (c) Le, Z. G.; Chen, Z. C.; Hu, Y.; Zheng, Q. G. Organic reactions in ionic liquids: A Simple and Highly Regioselective $N$ Substitution of Pyrrole. Synthesis 2004, 1951-1954; (d) Le, Z. G.; Chen, Z. C.; Hu, Y.; Zheng, Q. G. Organic reactions in ionic liquids: an efficient method for the N-alkylation of benzotriazoles. $J$. Chem. Res. (S) 2004, 344-346; (e) Le, Z. G.; Chen, Z. C.; Hu, Y.; Zheng, Q. G. Organic Reactions in Ionic liquids: Organic Reactions in Ionic liquids: a simple highly regioselective or regiospecific substitutions of benzotriazole. Heterocycles 2004, 63, 1077-1081.

8. Wassercheid, P.; Welton, T. (Eds.) Ionic liquids in Synthesis; Wiley-VCH: Weinheim, Germany, 2002.

Sample availability: Contact the authors.

(c) 2006 by MDPI (http://www.mdpi.org). Reproduction is permitted for noncommercial purposes. 